\title{
UNIVERSITYOF
}

FORWARD

THINKING

WESTMINSTER用

WestminsterResearch

http://www.westminster.ac.uk/westminsterresearch

\section{An overview of benefits and challenges of building information modelling (BIM) adoption in UK residential projects} Georgiadou, $\mathbf{M}$.

This article is (C) Emerald and permission has been granted for this version to appear here: http://westminsterresearch.westminster.ac.uk/

Emerald does not grant permission for this article to be further copied/distributed or hosted elsewhere without the express permission from Emerald Group Publishing Limited.

The final, published version in Construction Innovation, 19 (3), pp. 298-320, 2019 is available at:

https://dx.doi.org/10.1108/Cl-04-2017-0030

The WestminsterResearch online digital archive at the University of Westminster aims to make the research output of the University available to a wider audience. Copyright and Moral Rights remain with the authors and/or copyright owners.

Whilst further distribution of specific materials from within this archive is forbidden, you may freely distribute the URL of WestminsterResearch: ((http://westminsterresearch.wmin.ac.uk/)).

In case of abuse or copyright appearing without permission e-mail repository@westminster.ac.uk 


\title{
An overview of benefits and challenges of Building Information Modelling (BIM) adoption in UK residential projects
}

\begin{abstract}
This paper sets out to present a state-of-the-art review of Building Information Modelling (BIM) in the UK construction practice. In particular, the aim is to examine the scope, value and practical implications of BIM implementation in residential projects by evaluating practitioners' perspectives working in the Greater London Area (GLA). The paper outlines the general status quo of BIM adoption and maturity in the UK. It then discusses the feasibility of BIM use in residential projects drawing on an online survey and complementary semistructured interviews with building professionals. The cross-comparison between the evidence base and literature review uncovers the specific benefits, challenges and risks to BIM implementation in the house building sector.

BIM is an evaluation methodology that helps the management of digital information throughout the project lifecycle. At a conceptual level, a BIM-enabled project offers: quality assurance and on-time delivery; collaboration and communication improvement; visual representation and clash detection; and, whole lifecycle value. The findings, however, suggest that the most frequently reported benefits are related to collaboration and the blend of product (software) and process innovation; whilst, lifecycle thinking and waste reduction are often overlooked. At present, there is widespread awareness on BIM but with a financial barrier to invest in developing digital capabilities, particularly for Small-Medium Enterprises (SMEs). The paper concludes with a critical commentary on the lack of strategic leadership in both the supply and demand side. The role of policy to streamline commercial drivers for whole lifecycle costing in procurement is endorsed in order to drive the change management required to address the short-term mindset of senior management and wider fragmentation of the construction industry, also serving as a research question for further research and development in the field.
\end{abstract}

\section{KEYWORDS}

BIM, housing, information management, information systems, knowledge management, project management, whole lifecycle.

\section{Introduction}

Construction projects have complex physical and functional attributes, with technological innovation and sustainability two key features currently affecting design, construction and Facilities Management (FM). Traditionally, buildings and infrastructure were designed, built and managed by the use of 2D drawings and paper-based documentation. The introduction of 3D Computer-Aided Design (CAD) transformed labour-intensive drafts into more efficient documentation (Ondogan and Erdogan, 2006). This is now superseded by Building Information Modelling (BIM), which is a shared knowledge platform with integrated digital models. BIM uses 3D, real-time, dynamic modelling software to increase collaboration and productivity and to maximise whole lifecycle value (Dainty et al., 2015). The BIM model can also incorporate digital data on time/ scheduling (4D) and cost elements (5D), while asset management (6D) is expected to offer a holistic, lifecycle approach impacting on FM (Digital Construction Review, 2016; Gudgel, 2008).

The UK construction sector employs $2.9 \mathrm{~m}$ people and contributes to $6.7 \%$ of the country's GDP (HM Government, 2013). Construction is an enabling sector to all other industries. At the 
same time, however, it is considered an inefficient and wasteful industry with total waste between 30-35\% (UK Construction Online, 2016). The knock-on effect of institutionalised inefficiencies in UK construction cascades down to all infrastructure and building projects, as "inefficiency gets driven through the entire economy" (UK Construction Online, 2016). The UK Government is also the single biggest client at a national level, with public projects accounting for $40 \%$ of all construction works (NBS, 2014). To drive by change, the UK Construction Strategy 2025 has set a number of ambitious performance targets to be achieved by 2025; namely (HM Government, 2013):

- Lower costs: $33 \%$ reduction in capital cost of construction and whole life cost of built assets.

- Faster delivery: 50\% reduction in overall time, from inception to completion for both newbuild and refurbished assets; and

- Lower emissions: $50 \%$ reduction in greenhouse gas emissions in the built environment; and

- Improvement in exports: $50 \%$ reduction in the trade gap between total exports and total imports for construction products and materials.

The UK Government's BIM Level 2 mandate helped the construction industry to become a world leader in BIM adoption (Alwan et al., 2017; Eadie et al., 2015b). The BIM mandate was introduced in the Government Construction Strategy and the Industrial Strategy in 2013 and came into effect in April 2016. The mandate requires use of 3D collaborative BIM Level 2 models on all government-funded projects from 2016 onwards (HM Government, 2013). The shift to digital construction is also endorsed by the Government Construction Strategy 20162020 with the intention to gradually move to BIM Level 3, under fully-integrated built environment collaboration (HM Government, 2015; Infrastructure and Projects Authority, 2016).

In recent years, a number of scholars have investigated the generic barriers to and drivers for BIM implementation (Arayici et al., 2012, 2011a, 2011b; Azhar and Cochran, 2009; Bryde et al., 2013; Eadie et al., 2015a, 2013; Khosrowshahi and Arayici, 2012; McGraw Hill, 2014; Migilinskas et al., 2013; Motawa and Almarashad, 2013; Succar, 2009). There has been a significant 'push-pull' effect of the Government strategy which has promoted the use of BIM in various building typologies, as the new standard for project information (Machado et al., 2016). However, there is limited empirical research on the views and experiences of building professionals working specifically on BIM-enabled residential projects in the UK.

The paper is separated into two sections. Firstly, it consists of a desk study on the general status $q u o$ of BIM adoption and maturity in the UK. The objective is to provide a balanced assessment of the general benefits, challenges and risks of BIM implementation. Secondly, empirical data is gathered to assess the feasibility and 'real-life' value of BIM in housing practice, drawing on views and experiences of building professionals in GLA, with two specific objectives; namely, to:

- provide an evidence-base evaluating the extent to which the house building industry has the expertise and capability to operate in a BIM environment and to comply with the Level 2 mandate; and,

- explore which of the generic barriers and drivers of BIM-readiness are more relevant to the design and construction of housing projects.

The scope of this second part is focusing on residential buildings in the UK; it does not extend to other typologies. There is a growing body of literature suggesting that BIM adoption varies significantly from one industry sector to another (Alwin, 2016; Chaves et al., 2015; Gholami et al., 2013). In the UK, BIM uptake in the domestic sector is only at 25\% (Park and Kim, 
2014). At the same time, housing is a priority research area, which differentiates residential developments from any other building project. It is also the sector with the longest lifecycle, the worst environmental performance and the least available funds to apply sophisticated design approaches (Bosher et al., 2007; Greenwood et al., 2016). As Bosher et al. (2007, p.28) suggest: "residential developers are not proactive, motivated by profits and legal aspects, possibly at the cost of resilience and sustainability". These issues are also exacerbated by the current housing shortage and recession. There is an average of 137,000 homes per year over the last 10 years in England (Coelho et al., 2017), yet there is a need to build around 240,000 homes annually to accommodate the population increase (Holmans, 2013). Park and Kim (2014) argue that the challenge of BIM integration in the residential sector is a result of the fragmentation and complex stakeholder engagement. This is particularly relevant for retrofit projects that have higher risk compared to new-builds and therefore collaboration and integration during the project lifecycle (Gholami et al., 2013).

\section{Overview of BIM in the UK policy and construction practice}

Succar $(2009 ;$ p.357) provides a comprehensive definition of BIM as a "methodology to manage the essential building design and project data in digital format throughout the building's lifecycle". BIM is expected to be a major driver in enabling 3D visualisation and detailing, cost reduction, speeding-up the delivery time, highlighting service clashes, providing opportunities for value engineering, and reducing waste in all phases of design and construction. A BIM object is a combination of: information content; geometry; site surveys; and functional data about performance, materials, and quantities. For many scholars, BIM involves dynamic data management of the information generated and used during the project lifecycle; hence, it is not just a software tool. In addition, there are extensive studies on the value that BIM brings within the Integrated Project Delivery (IPD) and Integrated Project Insurance (IPI) frameworks. The American Institute of Architects (AIA, 2007; p.2) define IPD as a "novel project delivery approach that integrates people, systems, business structures and practices into a collaborative process". IPD is a combination of product (BIM model, software technology) and process (project management) innovation. BIM drives the formalisation of the conventional document management process into full integrated digital practice of the construction team, facilitating the transformation of the current fragmentation and inefficiency of the Architecture, Engineering, and Construction (AEC) sectors (Miettinen and Paavola, 2014). BIM is also discussed in relation to Lean Construction, particularly within the context of information management, both geometric and semantic (Gerber et al., 2010). The core concept of 'Lean' is synergetic to BIM. 'Lean' is process-oriented with the objective is to maximise value and minimise waste (Machado et al., 2016). There is therefore a growing body of literature realising BIM as a socio-technical process and this is why often BIM is referred to as Building Information Management and Modelling (BIMM) (Arayici et al., 2011a, 2011b; Chaves et al., 2015; Palos et al., 2014; Sinclair, 2012).

The BIM Task Group defined BIM maturity to ensure clear articulation of the levels of competence expected and the supporting standards and guidance notes for projects and contracts (BIM Task Group, 2011). The BIM Levels are well known and include (BIM Task Group, 2011; BSI Group, 2013; HM Government, 2015; Infrastructure and Projects Authority, 2016; NHBC, 2013; Succar, 2009):

- BIM Level 0: Unmanaged 2D CAD drawings, with paper (or electronic paper) as the most likely exchange mechanism.

- BIM Level 1: Object-based modelling in 2D or 3D CAD format with a collaboration tool providing a common data environment, possibly some standard data structures and formats. 
There is no integration of commercial data, which are managed by standalone finance and cost management packages.

- BIM Level 2: Managed 3D environment, which deals with the interchange (interoperable exchange) of separate disciplinary 3D models between one or two project lifecycle phases. Commercial data is often managed by an Enterprise Resource Planning application. There is also the potential to utilise programme data (4D), cost elements (5D) as well as FM (6D) models.

- BIM Level 3: Network-based data integration managed by a collaborative model server, which considers integrated models across all lifecycle stages. This is a fully open process compliant with emerging project standards; namely: Information Delivery Manual; Industry Foundation Classes; and, International Framework Dictionary. This also refers to as integrated BIM (iBIM).

According to the results of the 2017 National Building Specification (NBS) BIM survey, 62\% of construction professionals are currently aware and use BIM (NBS, 2017). BIM follows a normal adoption curve, which was only $13 \%$ in 2011 . It is therefore evident the change in roles of building professionals. At present, the 'BIM manager' is a distinct role, when back in 2010 it hardly existed (NBS, 2016; Sebastian, 2011). 78\% of NBS (2017) participants agree that BIM represents the "future of project information" enhancing energy efficiency, sustainability and overall effectiveness of project management. Furthermore, BIM is currently adopted in $48 \%$ (almost half) of small practices, whilst also used in $74 \%$ of medium and large organisations. Also, once BIM is adopted, it is usually the design methodology of choice. With regards to the Government Construction Strategy targets, 70\% of NBS (2017) participants support that BIM will help achieve lower costs, $60 \%$ faster delivery, $44 \%$ reduction in carbon emissions, and $32 \%$ an improvement in the trade gap in construction products.

\section{Review of BIM benefits}

A number of studies have evaluated the benefits of BIM on construction projects, comparing also the UK practice with international exemplars, such as Denmark, Singapore or Japan (Arayici et al., 2012, 2011a, 2011b; Arayici and Tah, 2008; Banuelos Blanco and Chen, 2014; Barlish and Sullivan, 2012; Bryde et al., 2013; Cant, 2012; Crotty, 2012; Eadie et al., 2015a, 2015b, 2013; Eastman et al., 2011; Farnsworth et al., 2015; Grilo and Jardim-Goncalves, 2010; Gudgel, 2008; Leaman et al., 2010; Pittard and Sell, 2016; Pramod Reddy, 2011; Sebastian, 2011; Singh et al., 2011; Succar, 2009; Volk et al., 2014, Yoders, 2013). The following sections discuss the key benefits and associated value of BIM in practice, which even though are still evolving, they are presented in five interconnected categories.

\section{Cost efficiency}

BIM has the ability to update, maintain, store and share data in multiple dimensions. A key advantage of this is in the efficiencies achieved at each stage of the project lifecycle, thus leading to cost reduction. Pittard and Sell (2016) argue that the connection between capital expenditure (CAPEX) and operational expenditure (OPEX) is an important consideration in successful BIM projects. BIM can reduce quantity take-offs affecting CAPEX but can also enhance accurate lifecycle cost estimations affecting OPEX; hence, these combined reduce the total expenditure (TOTEX) (Gudgel, 2008; Pittard and Sell, 2016; Pramod Reddy, 2011). Moreover, BIM goes beyond a $2 \mathrm{D}$ or 3D CAD application by providing more accurate information, which reduces the risk of making decisions based on assumptions from outdated drawings (Arayici et al., 2012, 2011a, 2011b; Arayici and Tah, 2008; Barlish and Sullivan, 2012; Bryde et al., 2013). Increased transparency in documentation leads to risk management 
and site safety through mitigating rework and accident prevention. BIM also supports lean construction, as improved design through collaboration and information sharing can eliminate added waste (hence, costs) in material supply and human resources (Eastman et al., 2011; Gerber et al., 2010, Volk et al., 2014).

\section{Quality assurance and on-time delivery}

BIM can enhance efficiency and accuracy leading to real-time scheduling of activities and potentially on-time delivery. Steel et al. (2012) explain how data management helps to perform tasks related to quantity surveying, procurement, and material supplier integration. With traditional closed systems, the gap between 'designed' and 'actual' scheduling activities often results in inaccurate forecasts, particularly for long-term projections. A BIM-enabled project however can overcome this barrier through evaluation of the design intent against the dynamic model of requirements and specifications. If interoperable data sharing is ensured, then this helps also to easily track production with support from schedules, thus highlighting delays and avoiding miscommunication (Grilo and Jardim-Goncalves, 2010).

\section{Collaboration and communication improvement}

The adoption of a shared set of standards and a common data environment sets the foundation for a novel integrated collaboration approach (Farnsworth et al., 2015; Sebastian, 2011). Banuelos Blanco and Chen (2014) and Yoders (2013) argue that BIM's greatest contribution is the ability to update models in real-time, eliminate clashes, discuss iterations early in the design process, and exchange valuable project information over the lifecycle. This enables effective communication and conflict resolution within an organisation and also with the various external stakeholders involved; namely: the client; design teams; and the contractor. BIM positions the project at the centre of communication, thus managing expectations and helping key actors to have shared goals during the project lifecycle. It can increase the likelihood for attracting leading clients, boosting their confidence, improving quality of the design and ensuring an overall more efficient and profitable project (Cant, 2012; Crotty, 2012; Sebastian, 2011). NBS (2017) suggests that BIM practice of collaboration and model sharing is commonplace within the design stages. 3D models are routine, produced also by $71 \%$ of NBS respondents. At present, the most commonly used standards for the collaborative production of information are:

- BS 1192:2007 + A2:2016, currently adopted by 39\% of NBS (2017) participants.

- PAS 1192-2:2013, which specifies the requirements for BIM Level 2, currently used by $38 \%$ of NBS (2017) participants.

Sharing models is also commonplace within (59\%) and outside (63\%) organisations, respectively (NBS, 2017).

\section{Design optimisation}

With BIM, buildings can be inspected from various angles including sub-structures, intersections and building performance characteristics (Crotty, 2012). Collaborative BIM allows for visual language tailored to different actors. Project stakeholders are able to retrieve and generate information from the same model, which is cloud-based and independent of software vendors (Farnsworth et al., 2015; Grilo and Jardim-Goncalves, 2010). For instance, BIM architects can integrate conceptual design using ArchiCAD and engineers can make detailed 3D structural designs using AutoDesk Revit. This is particularly helpful for large-scale projects with complex geometries, which require volumes of different technical documentation. At present, however, AutoDesk Revit is by $66 \%$ the most popular tool in the UK, followed by Graphisoft and Nemetscheck (NBS, 2017). Moreover, visual representation 
enables accurate decision-making through clash avoidance and clash detection, as it offers the ability to view a completed project. Hence, the complexity of rescheduling construction methods is reduced and the risk of costly rework is eliminated (Sebastian, 2011; Weygant, 2011).

\section{Lifecycle thinking and sustainability}

The role of BIM in the IPD framework is, at least theoretically, to account for the whole lifecycle for the project. $85 \%$ of total lifecycle costs of a building occur after construction is completed with clients and facility managers benefitting the most from BIM implementation (Arayici et al., 2012; 2011a, 2011b; Eadie et al., 2013). A visual replica of the building with 'as-built' documents and drawings maintained throughout the building lifecycle can guide FM teams and drive end-users' behaviours. In particular, BIM meta-data can enhance routine management (preventive maintenance) of the building fabric, heating systems, Building Management Systems, mechanical and electrical engineering works, fire detection systems and evacuation plans. It can also help with reactive (corrective) maintenance, as a response to a cause of failure or break down. BIM's ability to capture real-time data and performance evaluation helps to close the 'performance gap' between the 'as designed' and 'as delivered' assets and also to improve overall energy and environmental performance (NBS, 2017). BIM meta-data can provide fully populated Post-Occupancy Evaluation (POE) data for computeraided FM systems, as well as, feedback to the design and construction teams capturing lessons learned to inform carbon management in future projects. This is why BIM was mandated alongside the Government 'Soft Landings' policy, which is yet to be implemented by the UK central government departments from 2016 onwards (Leaman et al., 2010).

\section{Challenges and risks of BIM implementation}

Legislation can drive change and it is through the Government mandate that the UK construction industry has responded rapidly to BIM implementation (HM Government, 2013). A large number of practitioners have adopted BIM to enhance their commercial advantage and enable a longer-term value for their businesses (Arayici et al., 2011a, 2011b; Eadie et al., 2015a, 2015b, 2013). However, there is a growing body of academic literature examining the value of BIM in practice and concluding that there are unintended consequences of BIM deployment. There is the belief that large architectural practices should lead BIM implementation and a view that Small and Medium Enterprises (SMEs) are less likely to have adopted BIM, as clients of smaller organisations are not familiar enough with BIM or their projects are too small for BIM use (Arayici et al., 2012). According to Dainty et al. (2015), BIM is unlikely to stimulate innovation, collaboration and efficiency in project delivery on a wider scale, particularly for construction SMEs which account for $90 \%$ of all businesses in the UK (BIS, 2015). This is due to the underlying assumption that digital technology will deliver all above-mentioned benefits it claims and at all project scales (Sackey et al., 2015; Smiley et al., 2013). This technocratic optimism is what Dainty et al. (2015) refer to as "the BIM hype". There is therefore a disconnect between the appeal for BIM at a strategic policy level and readily-available strategies for wider adoption by the construction practice. As the rate of complex projects is increasing, many smaller organisations are reluctant in adopting BIM as they face major difficulties in meeting their objectives in a cost-effective manner (Rostami et al., 2015; Sackey et al., 2015). It is therefore essential to evaluate the perceived challenges and negatives of BIM evolution, which include: capital expenditure; reliability of the technology; legal issues and cyber security; client demand; and organisational culture (Arayici et al., 2012; Bryde et al., 2013; Dainty et al., 2015; Eadie et al., 2015a, 2015b, 2013; Grilo and JardimGoncalves, 2010; IET, 2014; Khosrowshahi and Arayici, 2012; Sebastian, 2011; Smiley, et al., 2013). However, while the focus on the 'BIM hype' tends to be more on product (technology) 
than process innovation, Machado et al. (2016) suggest that process improvements and knowledge management can incrementally reduce costs and increase competitiveness for SMEs.

\section{Financial barriers}

The price of BIM software packages is similar to that of common CAD software. Some vendors are selling packages that include both BIM and CAD platforms for the price of what used to be a CAD-only package. However, CAPEX and OPEX required for BIM adoption are a significant investment, particularly for SMEs. Since BIM is a relatively novel concept in construction, an obvious downside is the general lack of additional resources to finance its implementation. Higher costs are reported from 55\% of both small and large organisations combined in the UK (NBS, 2017). Moreover, limited in-house expertise in BIM modelling skills results in additional training costs. This affects both the individual practitioners and the organisation as a whole, highlighting the need for awareness raising and up-skilling within the AEC sector. A number of scholars argue that the increased cost of implementing BIM can be easily perceived as a substantial barrier within the construction industry. Despite this fact though, Eadie et al. (2013) and Hore et al. (2011) highlight that BIM implementation is a matter of training and client demand. The government mandate has been used as a means to spread awareness in the construction industry. The government seeks to build the profile and lead BIM implementation as an 'intelligent client' under the Digital Built Britain Strategy and its Industrial Strategy (HM Government, 2013; Infrastructure and Projects Authority, 2016). Eadie et al. (2013) suggest that practices of all sizes can meet the Government target and the additional costs are not beyond reach for small practices. This is correct particularly for the involved training, which should be considered as an investment rather than cost. Moreover, training costs could be eliminated or reduced significantly as soon as a learning curve is established through experience with implementing BIM within an organisation.

\section{Technological barriers}

Reliability and performance of the technology are frequently reported disadvantages of the BIM software. BIM computer models should ensure availability of information, systems and processes (IET, 2014). However, many existing systems do not support openness of data, which is a prerequisite for BIM collaboration. While open standards and open-source servers are available, there is a need to mainstream their application in the construction practice. BIM still depends on 'closed' applications; hence, openness, accessibility and extension possibilities of object libraries may be limited (Sebastian, 2011). Moreover, lack of interoperability is a key factor resulting in lack of collaboration amongst different vendors. Interoperability refers to the ability of two or more systems or components to exchange information without necessity of installing third party software. Packages may be unable to handle or exchange large amount of data and there is little knowledge and experience in software programming. Whilst interoperability issues vary between different BIM software packages, such technical issues are likely to be resolved as the technology matures in its response to BIM-related needs. BIM is also not sufficiently standardised yet. There is uncertainty in the evolving 'standardisation' framework of internal data (i.e. databases, spreadsheets and 3D drawings) to enable software and companies collaborate with each other (Sinclair, 2012; Succar, 2009). At present, security, interoperability, and shared language is established by PAS 1192-2 acting as the basis for two international BIM standards; namely (NBS, 2017):

- ISO 19650-1: information management of construction works (concepts and principles).

- ISO 19650-2: information management of construction works (delivery phase of assets). 


\section{Legal barriers and cyber security}

It is challenging to resolve legal issues related to the provision and exchange of electronic data. As the AEC industry becomes more digitalised, it is important to consider confidentiality, integrity of information models and data availability related to: liability for shared data (including subcontractors) and classified information on sharing platforms. Common issues involve: IP rights and protection related to cloud ownership; BIM technology disputes; and, information management responsibilities (BSI, 2015; IET, 2014). Shared data management has inherent cyber security risks due to technology failure. Scholars argue that BIM evolution has not yet established the appropriate mechanisms to address the risks associated with cyber security threats (Boyes et al., 2014; Litherland et al., 2016; Olatunji and Sher, 2010; Wang et al., 2013). Overall, cyber security threats are categorised in (IET, 2014): external threats (e.g. terrorism); internal threats (e.g. corrupted BIM data or disrupted operations); and, systems and business failures due to natural shocks, poor maintenance, or bankruptcy. To address these risks, project teams should ensure (BSI, 2015; IET, 2014):

- effective implementation of cyber security policies and procedures;

- cyber security awareness and education within an organisation;

- ongoing protection and monitoring of the project's technical infrastructure (e.g. network security, malware protection); and,

- ongoing protection and monitoring of operational BIM data to ensure confidentiality when personnel or collaborators change, integrity when models are updated, and data availability when storage technologies evolve over the project's lifecycle.

\section{Client demand}

NBS (2017) statistics show that $65 \%$ of clients do not understand the benefits of BIM and there is a need for greater client education. Small organisations are less confident about their BIM skills, with BIM adoption among smaller organisations currently at the levels that the wider industry was a few years ago (NBS, 2017). Migilinskas et al. (2013, p.767) emphasise that "obstacles are greater in small markets, were design and construction companies are small and have not enough resources to obtain and maintain theoretical BIM methodology”. However, the client's role is changing through the Digital Built Britain agenda. The Government Construction Strategy 2016-2020 discusses the potential for enhancing 'intelligent' client capabilities, underlining the importance of client leadership in digital design, early supply chain involvement, continuous improvement and collaborative culture.

\section{Cultural barriers}

This category involves challenges related to people and established cognitive practices. Contractual limitations in traditional procurement methods hinder effective implementation of a performance-based system; i.e., a system based on whole lifecycle assessment in project design and delivery. In addition, actors contracted through a traditional procurement approach realise no tangible (short-term) financial benefit to justify its use. BIM requires contractual relationships shifting from traditional to integrated procurement methods (Sebastian, 2011). In addition, the 'human factor' and the resistance to change could hinder effective collaboration between stakeholders. This refers to the intersection of established knowledge, experiences and behaviours of individuals and organisations during the adoption of a novel concept (in this case BIM), which requires substantial change in established mindsets and practices (Rostami et al., 2015). 


\section{Methodology}

The paper consists of a desk study, a questionnaire survey and complementary semi-structured interviews. Selection between a qualitative, quantitative, or mixed method approach is largely determined by practicalities, personal experience, the nature of the research questions, and the target audience. As Creswell (2008; pp. 21-23) suggests, a qualitative approach is merited when "a concept or phenomenon needs to be understood because little research has been done on it”, which is an effective approach as BIM is a growing research area. According to Lindlof and Taylor (2010) a survey can generate data for a baseline assessment of key variables.

A systematic literature review was followed in five steps to ensure that the research findings remain as unbiased as possible (Bowler et al, 2010; Pullin and Stewart, 2006). First, the objective was to frame the research question; i.e., to explore the benefits, challenges and risks related to the adoption of BIM in UK construction projects. Second, the study identified relevant resources in the field. Seminal peer-reviewed papers and reports in academic and UK industry databases published were reviewed. The main keywords were: 'BIM'; 'housing', 'information management', 'knowledge management', 'project management', and 'whole lifecycle'. The third step involved analysis of the quality of the existing studies, looking for groupings and relationships and the establishment of logical connections between the literature data. The fourth step summarised the evidence into five categories of benefits (cost efficiency, quality assurance and on-time delivery, collaboration and communication improvement, design optimisation, lifecycle thinking and sustainability) and five key challenges and risks associated with BIM implementation (financial, technological, legal barriers and cyber security, client demand, and cultural). Finally, the fifth step was to interpret the literature review findings by understanding the level of readiness of BIM adoption and maturity in the UK construction industry, before focusing more specifically on housing projects through the empirical research.

A structured online questionnaire was administered to 100 building professionals in GLA via Google Forms between February and April 2016 and generated 71 completed responses (71\% response rate). Three responses contained incomplete answers to some of the questions and were therefore disregarded. Participants were identified through snowballing techniques on LinkedIN and Facebook, as they were active in the following BIM-related groups; namely; UK Building Services \& Construction Professionals; RICS Building Information Modelling; and, UK Building Information Modelling. Prior to the survey, well-documented response facilitation approaches were conducted (e.g. pre-notifying participants, publicising the survey, piloting the questionnaire internally, providing survey feedback to participants). These methods helped to achieve higher response rates as argued by Baruch and Holtom (2008) and Rogelberg and Stanton (2007).

The web-based questionnaire comprised of nine multiple choice and rating questions. It was divided into three categories for systematic analysis; namely: the participants personal experience and the level of BIM use within an organisation; the advantages and disadvantages of BIM in residential projects; and, the future of BIM in terms of the value it brings/ may bring to the organisation. The survey also incorporated open-ended questions (to inquire comments) on the policy framework and the transition from CAD to BIM. Table 1 outlines the profile of the 71 survey respondents, of which $67 \%$ selected 'residential', as their organisation's main type of works. Figure 1 provides a detailed breakdown of participants' experience in the residential sector. Almost $60 \%$ of the respondents indicated that they had more than 15 years of experience, whilst $16 \%$ indicated they have less than five.

***** Place Table 1 \& Figure 1 here *****

Table 1: Participant profile by professional duties (survey data). 
Figure 1: Level of industry experience in the residential sector (survey data).

In addition to the survey, three complementary, in-depth semi-structured interviews were carried out with experts with over five years of experience in BIM on BIM-enabled housing projects in the UK. The objective was to triangulate and validate the survey findings and explore further the impact of digitalisation on project delivery. The interactive and non-rigid nature of the interviews elicited issues of importance to interviewees and allowed them to express freely their perspectives. Table 2 contains the list of interviewees, their affiliation and interview date. Interviews typically lasted about 60 minutes; all meetings were one-to-one and recorded, after receiving permission from participants. All interviews were transcribed in full and interview data are cited as: [Interview Number - Interview Date], for example (Int.218/07/2016).

***** Place Table 2 here *****

Table 2: Interview respondents.

Data analysis included an assessment of the 'real-world' perspectives generated by the survey and interview data against the literature review. By identifying the benefits, challenges and risks associated with the adoption of BIM in the domestic sector, the maturity and level of industry readiness were revealed.

\section{Research findings}

This section presents the findings from the analysis of the survey and interview responses. The empirical research indicates the different needs and expectations of the building professionals involved. $97 \%$ of all 71 respondents are aware of BIM, of which $45 \%$ are currently using BIM in residential projects and $63 \%$ indicate that they are currently operating at BIM Level 2. This is in line with the NBS (2017) report findings, as presented in the literature review. Figure 2 presents the respondents' experience with BIM between different age groups. The results suggest that groups between two to 15 years of experience have the highest knowledge of BIM, whereas $42 \%$ of those with more than 15 years of experience (often senior management) have combined poor or fair knowledge and, therefore, are still resistant to invest in digital capabilities.

***** Place Figure 2 here *****

Figure 2: BIM experience between different age groups (survey data).

\section{General points}

Participants were asked to evaluate their perception of BIM process and its usage in the residential sector. Figure 3 summarises the survey responses to different BIM related statements. Overall, BIM brings more than just monetary value to an organisation. As Interviewee 2 stated "BIM is the source of project information and with BIM we are on top of the curve, being able to talk intelligently to the client and to be seen ahead of other practices". $\mathrm{BIM}$ is perceived as a future-proofed design process and almost half of respondents in Figure 3 agree with the statement. This future use extends to the government mandate and over $30 \%$ believe that the mandate enabled them to use BIM on their projects. However, one third believe that BIM, as a future-oriented process, can provide satisfactory return on investment and there is also ambivalence on how trustworthy information about BIM is. 
Figure 3: BIM statements (survey data).

The majority of participants felt that BIM is just for large scale projects. However, one respondent commented that "BIM can offer, to varying degrees, value in any project regardless the size. Revision and co-ordination are improved and the peripheral benefits of $3 D$ work make BIM viable on any project". Over $77 \%$ agreed that $3 \mathrm{D}$ visualisation and clash detection process would significantly benefit refurbishment projects. However, over $30 \%$ are not clear on what they have to do to comply with BIM Level 2.

\section{Perspectives on BIM benefits}

Figure 4 indicates that $37 \%$ of the 71 respondents ticked the option that BIM is a process, whilst $21 \%$ argued that it is both 'a product, process and whole lifecycle thinking'. This demonstrates that for the majority of the participants BIM is not just a software model but it revolves around integrated collaboration, design and asset management processes.

$$
\text { ***** Place Figure } 4 \text { here } * * * * *
$$

Figure 4: BIM definitions (survey data).

Also, $48 \%$ of respondents highlighted that 'a shared building model' and $42 \%$ that 'communication and coordination with other disciplines' are the key advantages of using BIM. The latter is translated to around $25 \%$ of consultants, $50 \%$ of architects, $35 \%$ of contractors and $20 \%$ of clients, respectively. $10 \%$ of all respondents agreed that the shift from CAD to BIM enhances quality assurance, lower costs and on-time delivery. This is in-line with Interviewee 1 who mentioned that BIM enhances productivity and digital capabilities but "due to its novelty, creating the BIM model takes 4 to 6 weeks compared to CAD models and it is also quite time consuming to try adapt an existing BIM model developed by another organisation”.

$$
\text { ***** Place Figure } 5 \text { here ***** }
$$

Figure 5: BIM benefits for residential projects (survey data).

Focusing on specific disciplines, for $63 \%$ of contractors, visual representation of a BIM-enable project is useful from a marketing perspective particularly when tendering to a prospective client. In terms of clash detection, $40 \%$ architects and 35\% consultants highlighted the usefulness of BIM on service routes, quantity take-offs and scheduling of building elements, including secondary structures, such as upstands and parapets. Architects working in the 'design and build' environment mentioned that with a BIM process they become responsible for the geometry of the structure, such as fabric, balconies or upstands. They emphasised the value in clear detailing of complex interfaces (e.g. junctions), particularly on bespoke houses and/or high-rise mixed-use developments. These are construction details that engineers were normally responsible before BIM; hence, "the win with BIM is that the architect is much more the lead consultant that it would be with CAD” (Int.2-18/07/2016).

\section{Perspectives on BIM challenges}

BIM provides the basis for new dwelling designs and construction capabilities (Int.218/07/2016). It enables stakeholders to manage project information in a changing and virtual environment, across its several stages. However, respondents were specifically asked to prioritise the key reasons why BIM has not been adopted largely by the residential sector to date. Higher costs and lack of client demand are the most regularly mentioned barriers by all types of professionals. 'High capital costs' in software, technical maintenance and training, ranked first in Figure 6 covering 54\% of all survey responses (75\% of architects and 69\% of contractors), followed by $40 \%$ of 'lack of client demand' (50\% of architects and $50 \%$ 
contractors) and $15 \%$ of 'lack of previous experience'. This demonstrates that clients do not realise the value of BIM as "it needs to be cheap enough for clients to do it" (Int.2-18/07/2016).

***** Place Figure 6 here *****

Figure 6: BIM challenges for residential projects (survey data).

BIM requires investment in software and training as well as the capacity to run and operate software licenses, including awareness and education for enhanced cyber security. This is often difficult to finance due to the lack of resources, particularly for SMEs. According to Alwan (2016) this is outside the capacity of many housing associations' skills and capabilities. As BIM is in early adoption, practitioners follow a 'learning by doing' approach that is tailored to the organisation's knowledge and skills, as argued also by Interviewee 2 . There is an overall 'unwillingness to change' and the 'fear of the unknown' as a result of the short-term mindset of senior management, which focus predominantly on costs rather than the lifecycle value of the investment. As a principal contractor noted in the survey "there is no perceived need to change, residential developers are almost always guaranteed $20 \%$ profit and occupation and therefore they do not want anything different [...] house building companies and their supply chain are reactive to change; this combined with housing projects being generally not complex leads not to warrant the time and resources required for BIM". The demand for BIM in housing projects is also limited as clients do not want to feel that their projects are a BIM trial (Int.2-18/07/2016). Clients are used to 3D modelling software to produce plans, but they do not demand BIM information to populate their own models. The survey results suggest that this is a symptom of clients not realising the value that BIM can offer to their project, which is due to lack of skills and capabilities.

Survey respondents do not see the software technology and cyber security as key barriers to BIM implementation but rather the legal issues related to the data management process, particularly for BIM Level 3. These involve information management and exchange of the BIM model related to cloud ownership and IP rights. $75 \%$ of building professionals argued that they do not use an external recognised standard (e.g. PAS 1192-2) to establish a common data environment and consistently label information between organisations, for example during digital tendering of packages. Interviewee 1 argued that "not all organisations are geared up to manage information in a traditional manner, let alone a digital environment, or if they are they do not share the information". In addition, some BIM models contain too much information that is not relevant for all stakeholders. There is therefore the challenge of data validation and the problem of liability with shared data entered or interpreted incorrectly by other stakeholders along the project lifecycle. This causes data reliability and security issues, as different people may interpret information that goes into the BIM model differently.

\section{Discussion}

The BIM mandate generated a significant 'push-pull' effect (Machado et al., 2016), promoting the view that BIM is a new standard for project information across construction projects. However, BIM is an open-ended concept, as the term has various interpretations depending on the different professionals' background and experiences (Miettinen and Paavola, 2014). The survey results suggest that with BIM architects are much more of the lead consultant, organising activities in the design teams. The change in roles and responsibilities is key and BIM implementation should enable change management, process standardisation, shared metrics and investment in training. 


\section{BIM benefits}

The research findings are aligned with the literature review suggesting a number of benefits for residential projects that adopt BIM process applications, such as coordination, clash detection and 3D visualisation. However, there may be additional limitations for small or medium size projects as indicated by $30 \%$ of respondents who stated that BIM should be used primarily on new-builds, which is also argued by Ramanayaka and Venkatachalam (2015). The survey results also highlighted that, at present, BIM processes are implemented from a technical perspective and are intended to generate accurate and integrated 3D documentation, allowing clash detection and coordination between design team members. The findings have also shown that there are various socio-technical factors affecting occupants' intentions and preferences and BIM could potentially contribute to whole-house refurbishment for achieving the lowcarbon reduction target.

Going beyond housing projects, the study has shown that BIM brings technical competence and competitive advantage in the AEC industry as a whole. In the future, adopting BIM may be less risky and more cost-effective than not doing so. As with any innovation, there is inevitably much more that can be done with BIM, as knowledge and expertise are increasing. Another key advantage is the opportunity to integrate greater standardisation increasing project legacy (BSI Group, 2015, 2013). BIM improves accuracy, saves time and reduces costs by highlighting inefficiencies in all processes, including planning, design, procurement, human capital, and construction waste. More specifically, efficiency is improved in the time taken to estimate tenders, timely allocation of labour and resources, scheduling, clash avoidance and (if necessary) clash detection for all building elements. The survey findings suggest that BIM benefits are not necessarily associated specifically to large projects. This is aligned with Watt's (2015) argument that BIM adds value to all construction projects, including smaller ones. Only a few respondents specified projects at different price ranges and just over $10 \%$ believe that BIM process should be utilised purely on projects above $£ 3 \mathrm{M}$.

\section{BIM challenges}

The literature review revealed that BIM process utilisation on residential projects is an overall under-researched subject. According to the survey findings, the primary challenge to BIM adoption relates to the high cost of implementation (software and training), as discussed in Azhar (2011); Crotty (2012) and Eadie et al. (2014). In addition, client demand and resistance to change are two additional key challenges in implementing BIM, as highlighted in Figure 6, which is irrespective of an organisation's size or activity. A reason might be that particularly the retrofit sector is less demanding of BIM in residential buildings and that there is generally less push for innovation in the house building industry. Even though the government mandate has helped to raise awareness and realising the benefits of utilising BIM from the early design stages, the supply and demand side are not at the same level of BIM maturity in residential projects, and the lifecycle value is not yet evident to all project stakeholders. This is a difficult dynamic due to the lack of strategic leadership in both supply and demand. Building practitioners working on small scale projects are often reluctant to change or are not clear on how to comply with the BIM Level 2 mandate (Int.3-20/07/2016). The issue of fragmentation is also part of Volk's et al. (2014) argument that occupants and facility managers are hardly involved in BIM functionality development. In addition, despite the vision for a client-led BIM approach, the findings suggest that a BIM-enabled process does not necessarily lead to client satisfaction. This is a 'by-product' that can demonstrate to clients that the project risks are controlled more efficiently, which ultimately drives profitability. The demand side (e.g. clients, occupiers) should ask for BIM capability during tendering and the supply side should be exploring BIM to attract leading clients and understand how design and construction data will 
be used by them, as well as, improve profitability, increase efficiency and productivity (Digital Construction Review, 2016; HM Government, 2015).

A final challenge highlighted by the empirical research revolves around the locked-in inefficiencies in the interfaces of project phases, which are not transparent due to the fragmented nature of the industry. Interviewee 3 underlined that: "we cannot see what we need to improve, we do not see the waste explicitly, and we are constantly redesigning all the work and paying it time and time again. This is waste and BIM offers an opportunity to redefine waste in the construction sector". Machado et al. (2016) also claim that BIM can address the duplication of information, over-production, waiting, and/or defects, which are considered as waste, ultimately causing re-work.

\section{Future of BIM/ UK Government Construction Strategy}

Focusing on the domestic sector, BIM adoption can help improve the value of housing, "which is a social thing as much as anything else" (Int.3-20/07/2016). Compared to other building typologies, housing has the most standardised set of components and least complex geometries, which offers significant opportunities for BIM adoption and implementation. In addition to fabric and building services, Interviewees 2 and 3 commented that BIM in housing has an application for (Int.2-18/07/2016; Int.3-20/07/2016):

- developing sufficient metadata on monitoring and evaluation of various housing types; and

- raising awareness on maintenance and performance measurements (including POEs and energy monitoring).

However, NHBC (2013) found out that only $11 \%$ of major house builders in the UK are currently implementing BIM. To the same question of BIM application in housing, over $30 \%$ of survey participants favoured exclusively new-builds, as the high initial cost could be minimised if BIM is adopted from the early design stages. BRE studies have also consistently shown that BIM offers great opportunities to ensure design quality and address the 'performance gap' in new builds, without expensive retrofits (BRE, 2005; Park and Kim, 2014).

$40 \%$ of survey participants believe that BIM offers advantages to all housing typologies, including retrofits. Interviewees 2 and 3 commented also on the impact of BIM on the government commitment to reduce GHG emissions by $80 \%$ by 2050 , emphasising the challenge with retrofitting existing homes (Int.2-18/07/2016; Int.3-20/07/2016). If the construction industry is to successfully address the ambitious $80 \%$ carbon reduction target by 2050 , then it will be imperative that actions address existing dwellings. Currently, $45 \%$ of total UK emissions are generated from existing buildings, which also account for $27 \%$ of carbon emissions (Kelly, 2007). In the UK, there is also an ageing stock, as $87 \%$ of domestic buildings will be standing in 2050, resulting in high carbon emissions and increased energy consumption over new-builds. BIM's potential to be used for refurbishment projects has also been pointed out by the Government Industrial Strategy.

Lastly, participants were asked to comment on the role of BIM in achieving the Government Construction Strategy ambitious performance targets as set out by 2025 .

$$
\text { ***** Place Figure } 7 \text { here } * * * * *
$$

Figure 7: BIM aspirations towards the UK Construction Strategy 2025 (survey data).

Figure 7 shows that around $30 \%$ of participants point out that BIM will deliver $33 \%$ reduction in the initial cost of construction for a housing project. However, only $20 \%$ believe that BIM 
will help in the $50 \%$ reduction of project delivery time. Even fewer, just $10 \%$, agree with the statement that BIM will help achieve 50\% reduction in carbon emissions.

\section{Conclusions}

This paper presented an assessment of the scope, value and practical implications of BIM implementation, as there is little research on the specific benefits and barriers in the residential sector. Theoretical findings suggest that BIM is an integration of both product and process innovation. BIM brings cost efficiencies and is an effective tool for integrated built environment collaboration and ongoing data management. It embraces whole lifecycle asset management, thus promoting efficiency and productivity, speed of delivery, and increased profitability by reducing errors, rework and overall waste in construction.

However, BIM is not just a disparate set of software tools. Technological innovation should not be analysed separately from the socio-economic context of the implementing organisation. BIM effectiveness in residential developments is still in a transitional period, where challenges, such as higher CAPEX in software and training and lack of expertise need to be addressed. There is also lack of client demand and/or projects being too small to require BIM. The paper revealed that government support for the introduction of innovative processes in design and construction is essential so that BIM benefits are realised. Legislation is still the key driver for a change in industry mindsets towards BIM with direct implications for those responsible for setting regulatory requirements and voluntary standards. Resistance to BIM adoption around the world has generally revolved around a failure to be convinced of the business case, as the projected returns have not outweighed the costs and risks involved. Through the government mandate the UK is inverting this argument and has slowly created the demand for better value in construction projects, cascading down to the residential sector. Hence, if BIM is to become a tactical tool to enable identification and visualisation of inefficiencies throughout the project lifecycle, a clear policy framework is needed focusing on 'smart' regulation; i.e., identifying the right balance between regulatory and voluntary tools for a range of building typologies and project sizes.

The above considerations bring up the issue of skills and capabilities in both supply and demand. Uptake of new tools, techniques, and methods require significant time, skills and capital investment. Building practitioners, in general, and house building, in particular, need to address the lack of strategic leadership, build capacity and develop further their internal capabilities to operate in a digital environment. Some final specific opportunities pertaining to BIM implementation in residential projects that could be key aspects for both current and future policy and practice and are particularly useful to explore include:

- Developing an international evidence base of lessons learned in BIM-enabled residential projects. There is no 'one-size-fits-all' solution to BIM implementation as building projects are unique. Understanding the context-specific factors that lead to effective BIM adoption would help refine existing monitoring tools, processes and legal instruments of the implementing organisations in a continuous learning environment.

- Rethinking procurement as a strategy to bring change management for effective BIM implementation (Pittard and Sell, 2016). Business models and commercial drivers need to shift away from short-term CAPEX to whole lifecycle considerations, as " $£ 1$ spent in design it is worth $£ 10$ in construction and $£ 100$ in facilities management" (Int.320/07/2016). At present, price determination focuses purely on CAPEX and the standard economic theory of supply and demand (Pittard and Sell, 2016). Practitioners should realise 
the lifecycle value of BIM despite the increase CAPEX and integrate management theories of lean construction into their existing business models.

- Developing incentives for enhancing SMEs involvement in BIM-enabled projects. SMEs are vitally important in transforming the UK construction industry. For example, for housing projects over a certain size BIM compliance would be required for granting planning approval or, in turn, support in the form of complementary training should be provided to inexperienced project teams or SMEs.

- Adopting BIM as a means to promote the value of participatory design that entails the involvement of the demand side (i.e., client, portfolio landlords/ housing associations, occupants) in design decision-making (Damen et al., 2014). This is particularly relevant in supporting and developing improvements in the areas of energy efficiency (POE) and carbon saving in the housing stock. This would also help to address the performance gap, which is currently underreported due to complex decision making and complex stakeholder management in housing retrofits.

- Exploring BIM integration into process mapping and long-term performance monitoring, including clients' key performance indicators and ultimately facilities management.

- Investigating how BIM could be integrated into the delivery of collaborative built environment programmes of study in Higher Education, addressing the current skills and knowledge gap and bridging the traditional silos of a fragmented construction industry so that the full benefits of BIM are realised in the context of meeting the 2016 Government mandate.

\section{References}

Alwan, Z., Jones, P., Holgate, P., 2017, Strategic sustainable development in the UK construction industry, through the framework for strategic sustainable development, using Building Information Modelling, Journal of Cleaner Production, 140(1), 349 358.

Alwan, Z. 2016, BIM performance framework for the maintenance and refurbishment of housing stock, Structural Survey, 34(3), 242 - 255.

American Institute of Architects (AIA), 2007, Integrated Project Delivery: A Guide, AIA National and AIA California Council.

Arayici, Y. and Tah, J., 2008, Towards Building Information Modelling for Existing Structures, In: $11^{\text {th }}$ International Conference on Civil, Structural and Environmental Engineering Computing, Stirlingshire, 210 - 222.

Arayici, Y., Coates, P., Koskela, L., Kagioglou, M., Usher, C., O’Reilly, K., 2011a, BIM adoption and implementation for architectural practices, Structural Survey, 29(1), 7 25.

Arayici, Y., Coates, P., Koskela, L., Kagioglou, M., Usher, C., O’Reilly, K., 2011b, Technology adoption in the BIM implementation for lean architectural practice, Automation in Construction, 20, 189 - 195.

Arayici, Y., Onyenobi, T., Egbu, C., 2012, Building Information Modelling (BIM) for Facilities Management (FM): The Mediacity Case Study Approach, International Journal of 3D Information Modelling, 1(1), 55 - 73. 
Azhar, S. and Cochran, S., 2009, Current Status of Building Information Modelling (BIM) Adoptability in the US Electrical Construction Industry, In: $5^{\text {th }}$ International Conference on Construction in the 21 st Century $(C I T C-V)$.

Banuelos Blanco, F. G. and Chen, H., 2014, The implementation of Building Information Modelling in the UK by the transport industry, Procedia - Social and Behavioural Sciences, 138, $510-520$.

Barlish, K. and Sullivan, K., 2012, How to measure the benefits of BIM - A case study approach, Automation in Construction, 24, 149 - 159.

Baruch, Y., and Holtom, B., 2008, Survey response rate levels and trends in organisational research, Human Relations, 61(8), 1139 - 1160.

BIM Task Group, 2011, Strategy Paper for the Government Construction Client Group, BIM Industry Working Group, Department of Business, Innovation and Skills, URN 11.

Bosher, L., Dainty, A., Carrillo, P., Glass, J., Price, A., 2007, Integrating disaster risk management into construction: A UK perspective, Building Research \& Information, 35(2), pp. 163-177.

Bowler, D., Buyung-Ali, L., Knight, T., Pullin, A., 2010, Urban greening to cool towns and cities: A systematic review of the empirical evidence, Landscape and Urban Planning, 97(3), $147-155$.

Boyes, H.A., Isbell, R., Norris, P. and Watson, T., 2014, Enabling Intelligent Cities through Cyber Security of Building Information and Building Systems, In: Future Intelligent Cities, IET Conference, London, UK.

Bryde, D., Broquetas, M., Volm, J. M., 2013, The project benefits of Building Information Modelling (BIM), International Journal of Project Management, 31, 971 - 980.

Building Research Establishment Ltd. (BRE), 2005, Putting a Price on Sustainability, BRE, Watford, UK.

BSI Group, 2013, PAS 1192-2:2013, Specification for information management for the capital/ delivery phase of construction projects using building information modelling, London.

BSI Group, 2015, PAS 1192-5:2015, Specification for security-minded building information modelling, digital built environment and smart asset management, London.

Building Research Establishment Ltd. (BRE), 2005, Putting a Price on Sustainability, BRE, Watford, UK.

Cant, D, 2012, Realising the Benefits of BIM, Available from: http://www.veritasconsulting.co.uk/blog/bim-consulting-services-building-information-modellingexplained/ (Accessed: 14 ${ }^{\text {th }}$ March 2016).

Chaves, F., Tzortzopoulos, P., Formoso, C., Shigaki, J., 2015, Using 4D BIM in the Retrofit Process of Social Housing. In: ZEMCH conference (Zero Energy Mass Custom Home), Lecce, Italy.

Coelho, M., Dellepiane-Avellaneda, S., Ratnoo V., 2017, The political economy of housing in England, New Political Economy, 22(1), 31 - 60.

Creswell, J., 2008, Research Design: Qualitative, Quantitative and Mixed Method Approaches, Sage, London.

Crotty, R., 2012, The impact of Building Information Modelling - Transforming Construction, Routledge, New York. 
Damen, T., MacDonald, M., Hartmann, T., Di Giulio, R., Bonsma, P., Luig, K., Sebastian, R., Soetanto, D., 2014, BIM Based Collaborative Design Technology for Collective SelfOrganised Housing, In: 40 th IAHS World Congress on Housing, Sustainable Housing Construction, Funchal, Portugal.

Dainty, A., Leiringer, R., Fernie, S., Harty, C., 2015, Don't Believe the (BIM) Hype: The Unexpected Corollaries of the UK 'BIM Revolution', In: Conference Proceedings of the Engineering Project Organisation Conference, Edinburgh.

Department of Business, Innovation and Skills (BIS), 2015, Statistical Release - Business Population Estimates for the UK and Regions 2015, Sheffield.

Digital Construction Review, 2016, Current and Projected Adoption of Digital Technologies and Practices in the Construction, A report by Building, BD and Ecobuild.

Eadie, R., Browne, M., Odeyinka, H., McKeown, C., McNiff, S., 2015a, A survey of current status of and perceived changes required for BIM adoption in the UK, Built Environment Project and Asset Management, 5(1), 4 - 21.

Eadie, R. McLernon, T., Patton, A., 2015b, An Investigation into the Legal Issues Relating to Building Information Modelling (BIM), In: RICS COBRA AUBEA 2015, Sydney, Australia, Royal Institution of Chartered Surveyors.

Eadie, R., Browne, M., Odeyinka, H., McKeown, C., McNiff, S., 2013, BIM implementation throughout the UK construction project lifecycle: An analysis, Journal of Automation in Construction, 36, 145 - 151.

Eastman, C., Teicholz, P., Sacks, R., Liston, K., 2011, BIM Handbook: A Guide to Building Information Modelling for Owners, Managers, Designers, Engineers and Contractors, Wiley Publishing, $2^{\text {nd }}$ edition.

Farnsworth, C., Beveridge, S., Miller, K., Christofferson, J., 2015, Application, advantages, and methods associated with using BIM in commercial construction, International Journal of Construction Education and Research, 11(3), 218 - 236.

Gerber, D., Becerik-Gerber, B., Kunz, A., 2010, Building Information Modeling and Lean Construction: Technology, Methodology and Advances from Practice, In: 18 ${ }^{\text {th }}$ Annual Conference, International Group for Lean Construction, Haifa, Israel.

Gholami, E., Sharples, S., Abrishami, S., Kocaturk, T., 2013, Exploiting BIM in Energy Efficient Refurbishment: A Paradigm of Future Opportunities, In: W. Lang (Ed.), EBook of Proceedings PLEA 2013 Munich: Sustainable Architecture for a Renewable Future, Fraunhofer IRB Verlag, Stuttgart, Germany.

Greenwood, D., Congreve, A., King, M., 2016, The Future of Policy and Standards for Low and Zero Carbon Homes, Report published by the Royal Institution of Chartered Surveyors (RICS), London.

Grilo, A and Jardim-Goncalves, R., 2010, Value proposition on interoperability of BIM and collaborative working environments, Journal of Automation in Construction, 19(5), $522-530$.

Gudgel, J., 2008, Building Information Modelling: Transforming Design and Construction to achieve greater industry productivity, McGraw-Hill SmartMarket Report.

Holmans, A., 2013, New Estimates of Housing Demand and Need in England, 2011 to 2031, Town and Country Planning, Tomorrow Series Paper 16, Town and Country Planning Association, London. 
Hore, A., Montague, R., Thomas, K., Cullen, F., 2011, Advancing the Use of BIM through a Government Funded Construction Industry Competency Centre in Ireland, In: CIB W78 28th International Conference, Paris, France.

HM Government, 2013, Construction 2025, Industrial Strategy: Government and Industry in Partnership, London.

HM Government, 2015, Digital Built Britain Level 3 Building Information Modelling Strategic Plan, London.

IET, 2014, Building Information Modelling (BIM); Addressing the Cyber Security Issues, Institution of Engineering and Technology (IET), London.

Infrastructure and Projects Authority, 2016, Government Construction Strategy 2016-2020, London.

Khosrowshahi, F. and Arayici, Y., 2012, Roadmap for implementation of BIM in the UK construction industry, Journal of Engineering, Construction and Architectural Management, 19(6), $610-635$.

Leaman, A., Stevenson, F., Bordass, B., 2010, Building evaluation: Practices and principles, Building Research and Information, 38(5), 564 - 577.

Lindlof, T.R. and Taylor, B.C., 2010, Qualitative Communication Research Methods, Sage.

Litherland, P., Orr, R., Piggin, R., 2016, Cyber Security of Operational Technology: Understanding Differences and Achieving Balance between Nuclear Safety and Nuclear Security, In: $11^{\text {th }}$ International Conference on System Safety and CyberSecurity (SSCS 2016), London, UK.

Machado, M., Underwood, J., Fleming, A., 2016, Implementing BIM to Streamline a Design, Manufacture and Fitting Workflow. In: Modular and Offsite Construction [MOC] Summit, Edmonton, Alberta, Canada.

McGraw Hill, 2014, The Business Value of BIM for Construction in Major Global Markets, MCGraw Hill Construction, Research \& Analytics, Bedford.

Miettinen, R. and Paavola, S., 2014, Beyond the BIM utopia: Approaches to the development and implementation of building information modelling, Automation in Construction, 43, pp. $84-91$.

Migilinskas, D., Popov, V., Juocevicius, V., Ustinovichius, L., 2013, The benefits, obstacles and problems of practical BIM implementation, Procedia Engineering - Modern Building Materials, Structures and Techniques, 57, 767 - 774.

Motawa, I. and Almarashad, A., 2013, A knowledge-based BIM system for building maintenance, Journal of Automation in Construction, 29, 172 - 182.

National Building Specification (NBS), 2014, NBS National BIM Report 2014, Royal Institute of British Architects, London.

National Building Specification (NBS), 2016, NBS National BIM Report 2016, Royal Institute of British Architects, London.

National Building Specification (NBS), 2017, NBS National BIM Report 2017, Royal Institute of British Architects, London.

NHBC, 2013, Building Information Modelling: An Introduction for House Builders, National House-Building Council Foundation, Milton Keynes. 
Olatunji, O.A. and Sher, W., 2010, Legal Implications of BIM: Model Ownership and Other Matters Arising, In: W113-Special Track 18th CIB World Building Congress, Salford, UK.

Ondogan, Z. and Erdogan, C., 2006, The comparison of the manual and CAD systems for pattern making, grading and marker making processes, Fibres and Textiles, 14(1), 62 67.

Palos, S., Kiviniemi, A., Kuusisto, J., 2014, Future perspectives on product data management in building information modelling, Construction Innovation, 14(1), $52-68$.

Park, K., and Kim, K., 2014, Essential BIM Input Data Study for Housing Refurbishment: Homeowners' Preferences in the UK. Buildings, 4, 467-487.

Pittard, S. and Sell, P., 2016, BIM and Quantity Surveying, Routledge, Oxon.

Pramod Reddy, K., 2011, BIM for Building Owners and Developers: Making a Business Case for Using BIM on Projects, Wiley, UK.

Pullin, A and Stewart, G., 2006, Guidelines for systematic review in conservation and environmental management, Conservation Biology, 20, 1647 - 1656.

Ramanayaka, C. and Venkatachalam, S., 2015, Reflection on BIM development practices at the pre-maturity, Procedia Engineering, 123, $462-470$.

Rogelberg, S. and Stanton, J., 2007, Understanding and dealing with organizational survey non-response, Organizational Research Methods, 10, 195 - 209.

Rostami, A., Khodadadyan, A., Sommerville, J., Wong, I. L., 2015, Training provisions for risk management in SMEs in the UK construction industry, In: Conference Proceedings of the $31^{\text {st }}$ Annual ARCOM Conference, Lincoln.

Sackey, E., Tuuli, M., Dainty, A., 2015, Sociotechnical Systems Approach to BIM Implementation in a Multidisciplinary Construction Context, Journal of Management in Engineering, Special Issue, 31(1), no page.

Sebastian, R., 2011, Changing roles of the clients, architects and contractors through BIM. Journal of Engineering Construction and Architectural Management, 18(2), 176 - 187.

Sinclair, D., 2012, BIM Overlay to the RIBA Outline Plan of Work, Royal Institute of British Architects, London.

Singh, V., Gu, N., Wang, X., 2011, A theoretical framework of a BIM-based multi-disciplinary collaboration platform, Automation in Construction, 20(2), 134 - 144.

Smiley, J.-P., Dainty, A., Fernie, S., 2013, Analysing the Discourses Surrounding Change and Reform in the Construction Sector: The Need for a Marriage between Critical Theory and a Socio-Historical Cultural Perspective, In: Smith, S.D. and Ahiaga-Dagbui, D.D. (eds). Proceedings 29th Annual ARCOM Conference, Reading, UK.

Steel, J., Drogemuller, R., Toth, B., 2012, Model interoperability in building information modelling, Software \& Systems Modelling, 11(1), 99 - 109.

Succar, B., 2009, Building information modelling framework: A research and delivery foundation for industry stakeholders, Journal of Automation in Construction, 18, 357 375.

UK Construction Online, 2016, Why I have the best job in the world, Available from: http://www.ukconstructionmedia.co.uk/features/why-i-have-the-best-job-in-theworld/ (Accessed: 10 ${ }^{\text {th }}$ July 2016). 
Volk, R., Stengel, J., Schultmann, F., 2014, Building Information Modelling (BIM) for existing buildings - Literature review and future needs, Automation in Construction, 38, 109 127.

Weygant, R., 2011, BIM Content Development: Standards, Strategies and Best Practices, Wiley, UK.

Wang, J., Li, S., Wang, X., Mao, C. and Guo, J., 2013, The application of BIM-enabled facility management system in complex building, International Journal of 3-D Information Modelling (IJ3DIM), 2(3), 16 - 33.

Watt, R., 2015, Building Information Modelling: A study into the suitability of BIM within projects with construction values of less than $£ 5 \mathrm{M}$, WIT Transactions on The Built Environment, 149, 317 - 328.

Yoders, J., 2013, Collaboration: How architects and engineers can work together with BIM in the cloud, Available from: http://lineshapespace.com/how-architects-and-engineerscan-work-together-with-bim-in-the-cloud/ (Accessed: 14 ${ }^{\text {th }}$ June 2016). 